\title{
Current Evidence on the Use of Antifilarial Agents in the Management of Bancroftian Filariasis
}

\author{
Sumadhya Deepika Fernando, ${ }^{1}$ Chaturaka Rodrigo, ${ }^{2}$ and Senaka Rajapakse ${ }^{3}$ \\ ${ }^{1}$ Department of Parasitology, Faculty of Medicine, University of Colombo, Colombo 08, Sri Lanka \\ ${ }^{2}$ University Medical Unit, National Hospital of Sri Lanka, Colombo 08, Sri Lanka \\ ${ }^{3}$ Department of Clinical Medicine, Faculty of Medicine, University of Colombo, Colombo 08, Sri Lanka
}

Correspondence should be addressed to Chaturaka Rodrigo, chaturaka.rodrigo@gmail.com

Received 25 September 2010; Accepted 29 November 2010

Academic Editor: Thomas R. Unnasch

Copyright (C) 2011 Sumadhya Deepika Fernando et al. This is an open access article distributed under the Creative Commons Attribution License, which permits unrestricted use, distribution, and reproduction in any medium, provided the original work is properly cited.

\begin{abstract}
Many trials have explored the efficacy of individual drugs and drug combinations to treat bancroftian filariasis. This narrative review summarizes the current evidence for drug management of bancroftian filariasis. Diethylcarbamazine (DEC) remains the prime antifilarial agent with a well-established microfilaricidal and some macrofilaricidal effects. Ivermectin (IVM) is highly microfilaricidal but minimally macrofilaricidal. The role of albendazole (ALB) in treatment regimens is not well established though the drug has a microfilaricidal effect. The combination of DEC+ALB has a better long-term impact than IVM+ALB. Recent trials have shown that doxycycline therapy against Wolbachia, an endosymbiotic bacterium of the parasite, is capable of reducing microfilaria rates and adult worm activity. Followup studies on mass drug administration (MDA) are yet to show a complete interruption of transmission, though the infection rates are reduced to a very low level.
\end{abstract}

\section{Introduction}

There are nine filarial nematodes causing disease in humans. According to the location of the parasite and the pathogenesis, the disease can be classified as lymphatic, subcutaneous, and serous cavity filariasis. Two filarial worms, namely, Wuchereria bancrofti and Brugia malayi cause lymphatic filariasis. The World Health Organization (WHO) considers lymphatic filariasis to be a global health problem affecting approximately 120 million people in over 80 countries [1]. One-third of affected individuals are from South Asia and another one third is from Africa [1]. One sixth of the world population is at risk of infection [1].

The adult $W$. bancrofti worms live within the human lymphatic system. They have a long life span of 4-6 years. Females are viviparous and release thousands of microfilaria into the blood stream of the host after mating. These are taken up by vector mosquitoes during feeding, and the parasite undergoes several moults within the intermediate host to become the L3 larva which is the infective stage. During a feed, this larva enters the human blood stream and migrates to the lymphatics where it moults to become an adult worm [2]. There is a range of clinical manifestations in bancroftian filariasis with asymptomatic microfilaremics being at one end of the spectrum. Symptomatic patients may have acute (lymphangitis, lymphadenitis), chronic (elephantiasis, lymphoedema, hydrocoele, chyluria), or atypical (funiculitis, mastitis) manifestations [3]. Some may suffer from tropical pulmonary eosinophilia (TPE) due to the immunological hyperresponsiveness to the parasite [4].

The disease burden of lymphatic filariasis is significant. Chronic disease causes serious disfiguration and incapacitation of the patient with resultant stigma and marginalization. It is a disease of the poor, and it significantly affects their ability to earn an income. Many chronically ill patients are nonproductive for the rest of their life and become a burden to family and society $[1,5,6]$. This review focuses on the drug treatment of lymphatic filariasis caused by $W$. bancrofti.

\section{Search Strategy and Methods}

A MEDLINE search was carried out for all articles with the key word "Wuchereria bancrofti" in any field. The search was 
restricted to articles published in English within the last 10 years (1999-2009), as they would contain more recent data. There were 659 abstracts in the original search with these restrictions. The software, Endnote X1.01 was used to filter articles. Bibliographies of cited literature were also searched. All abstracts were read through independently by the three authors, and relevant ones were identified for review of the full papers. Related papers were also included. Where the full paper was not available online or as hard copies, we contacted the authors and obtained the articles. Suitable data was available in 73 papers.

Sources were screened for a well-described methodology, accurate statistical analysis, and an adequate sample size where relevant. Coding was done by three reviewers independently blinded to each other. Interreviewer agreement for final review was $100 \%$. Data sources included reviews published in core clinical journals, cohort studies, interventional studies, case control studies, cross-sectional analysis, and epidemiological data. We reviewed $64(87.6 \%)$ full papers from a selected 73. A summary of the cited literature is shown in Tables 1 and 2.

One of the main issues that arose in evaluating the efficacy of therapies for bancroftian filariasis was the differences in outcome measures of treatment used in different trials. Of these we identified the following key outcome measures: (a) microfilaricidal effect, (b) clearance of antigenaemia, (c) macrofilaricidal effect, and (d) prevention of clinical effects or complications of filariasis. The key pharmacological regimens in the management of lymphatic filariasis are, diethylcarbamazine (DEC), albendazole (ALB), and ivermectin (IVM) either used alone or in combination. We assessed the efficacy of each of these drugs or drug combinations in achieving the above-mentioned outcome measures. The value of these drugs in treatment of the individual and with regards to mass treatment, were considered separately.

\section{Standard Treatment with DEC}

DEC has been used to treat lymphatic filariasis for over 50 years. Its mechanism of action is still not fully understood. Earlier studies suggested that DEC had no direct effect on microfilaria as exposure to high concentrations of DEC left them unharmed [7]. Later, evidence from in vitro studies suggested that DEC blocks the cyclooxygenase pathway in parasites and leads to death of microfilaria [8]. Peixoto et al. [9] have demonstrated that DEC induces apoptosis in W. bancrofti microfilaria following exposure. Due to this microfilaricidal activity of DEC, the blood is cleared of microfilariae and the opportunity for mosquito borne transmission to occur is reduced. Further, filariaassociated haematuria and proteinuria are reversed. The macrofilaricidal action of DEC is not intended to reverse existing lymphatic damage but prevent further adult worm associated lymphatic damage and dysfunction [10]. The 12-day regimen of $72 \mathrm{mg} / \mathrm{kg}$ of DEC treatment remained the standard treatment for bancroftian filariasis for many years [11]. However, currently studies have indicated that single-dose treatment with $6 \mathrm{mg} / \mathrm{kg}$ DEC has comparable macrofilaricidal and long term microfilaricidal efficacy, and this has been discussed. The 12-day course of DEC provides more rapid short-term microfilarial suppression, but when other factors are considered, including cost, convenience, and patient compliance it seems feasible to recommend single-dose treatment for individual patients with $W$. bancrofti infection. Single-dose treatment can be repeated every 6-12 months for persons who remain infected. However the 12-day regimen which reduces microfilarial density more rapidly is recommended for patient with TPE or hematuria, both of which are associated with microfilariae rather than the adult worm [12]. DEC is not used in areas endemic for onchocerciasis due to an increased side effect profile $[13,14]$.

\section{Evidence from Clinical Trials on Antifilarial Agents}

4.1. Single-Dose Treatment. Single dose treatment with DEC is as effective as the older standard 12-day course of DEC, but has fewer adverse effects and results in enhanced population compliance and decreased delivery costs [15]. Single-dose therapy with DEC has been assessed in several trials (Table 1). In a prospective study in Egypt, a single dose of DEC achieved a microfilaria-clearance rate of $69 \%(n=20)$ after 1 year while the reduction in antigenaemia was less satisfactory ( $n=86,40.7 \%)$ [16]. A prospective trial in Sri Lanka recorded a $74-80 \%$ reduction in microfilaria density (19$28 \%$ microfilaria-clearance rate) with a single dose of DEC $6 \mathrm{mg} / \mathrm{Kg}$, 1 year after treatment [17]. However, the benefit of a single dose therapy may not be long lasting, as shown in a 10-year followup study in Orissa, India [18]. In this study of 44 patients, only $57 \%$ and $18 \%$ tested negative for microfilaria and antigenaemia, respectively, at the end of the followup period of 10 years after a single standard dose of DEC. Similar evidence comes from Freedman et al. [19] who demonstrated significant levels of antigenaemia (clearance rate of only $12 \%$ ) at two years despite a more aggressive treatment regimen with DEC (repeated dosing with $6 \mathrm{mg} / \mathrm{kg}$ for 12 days at $0,6,12,18$ months).

Pani et al. [20] demonstrated that either single dose administration of DEC, ALB, or combination therapy were not different from each other with regard to microfilariaclearance rates and reducing antigenaemia $(P>.05)$. Marked reduction in mean geometric parasite density $(P<.05)$ as well as antigenaemia optical density $(P<.01)$ was seen in all groups at followup in 1 year.

Ivermectin is the third drug used in the treatment of bancroftian filariasis. Regarding monotherapy with IVM, Stolk et al. [21] demonstrated that single dose IVM alone can achieve a high microfilaria kill rate and a worm productivity loss at 1 year (96\% and $82 \%$ on average, resp.). In comparison, the rates for the DEC treated group were very much lower $(57 \%$ and $67 \%$, resp.). Interestingly a similar trial by Reddy et al. [22] (with high-dose IVM) who followed up patients for two years suggests that both the tolerability and efficacy of the two drugs (IVM, DEC) were not significantly different between gender, age, and weight classes of patients at two years, although IVM showed a better 
TABLE 1: Summary of clinical trials on drug treatment quoted in text.

\begin{tabular}{|c|c|c|c|}
\hline Authors & Year & Study design & Drug doses \\
\hline Bockarie et al. & 2007 & $\begin{array}{l}\text { Randomized } \\
\text { controlled clinical } \\
\text { trial }\end{array}$ & $\begin{array}{l}\text { Single-dose DEC at } 6 \mathrm{mg} / \mathrm{kg} \text { versus } \\
\text { DEC plus ALB } 400 \mathrm{mg} \text { single dose }\end{array}$ \\
\hline Fox et al. & 2005 & $\begin{array}{l}\text { Randomized placebo- } \\
\text { controlled trial four } \\
\text { arms }\end{array}$ & $\begin{array}{l}\text { (i) DEC } 6 \mathrm{mg} / \mathrm{kg} \text { single dose } \\
\text { (ii) ALB } 400 \mathrm{mg} \text { single dose } \\
\text { (iii) Combination of both } \\
\text { (iv) Placebo }\end{array}$ \\
\hline Hussein et al. & 2004 & $\begin{array}{l}\text { Prospective study two } \\
\text { arms }\end{array}$ & $\begin{array}{l}\text { (i) DEC } 6 \mathrm{mg} / \mathrm{kg} \text { and ALB } 400 \mathrm{mg} \\
\text { single dose } \\
\text { (ii) Same repeated daily for } 7 \text { days }\end{array}$ \\
\hline El Setouhy et al. & 2004 & $\begin{array}{l}\text { Randomized clinical } \\
\text { trial two arms }\end{array}$ & $\begin{array}{l}\text { (i) DEC } 6 \mathrm{mg} / \mathrm{kg} \text { and ALB } 400 \mathrm{mg} \\
\text { single dose } \\
\text { (ii) Same repeated daily for } 7 \text { days }\end{array}$ \\
\hline Pani et al. & 2002 & $\begin{array}{l}\text { Double-blind hospital } \\
\text { based clinical trial } \\
\text { three arms }\end{array}$ & $\begin{array}{l}\text { (i) DEC } 6 \mathrm{mg} / \mathrm{kg} \text { single dose } \\
\text { (ii) ALB } 400 \mathrm{mg} \text { single dose } \\
\text { (iii) Combination of both }\end{array}$ \\
\hline Dreyer et al. & 2006 & $\begin{array}{l}\text { Randomized } \\
\text { controlled clinical } \\
\text { trial two arms }\end{array}$ & $\begin{array}{l}\text { (i) DEC } 6 \mathrm{mg} / \mathrm{kg} \text { single dose } \\
\text { (ii) DEC } 6 \mathrm{mg} / \mathrm{kg}+\text { ALB } 400 \mathrm{mg} \text { single } \\
\text { dose }\end{array}$ \\
\hline
\end{tabular}

Ramzy et al. 2002 Prospective study Single-dose DEC 6 mg/kg

Weerasooriya et al. 1998 Prospective study Single-dose DEC 6 mg/kg

Outcome

No difference in microfilaricidal effect but combination therapy had more macrofilaricidal effect.

Combination therapy has a significant microfilaricidal effect than either DEC or ALB used alone.

Combination therapy reduced adult worm activity by $90 \%$ after 1 year. No benefit of multiple dosing versus single dosing beyond 3 months.

Greater and significant microfilaricidal effects 1 year after treatment (effect on adult worms were similar) for multiple dose combined therapy.

Single dose administration of DEC, ALB, or combination therapy were not different from each other with regard to microfilaria-clearance rates and reducing antigenaemia.

Significant reduction in macrofilaricidal effect in the combined regime compared to DEC alone $(P=.016)$ with no additional effect on microfilaria rates.

DEC single dose therapy achieved a microfilaria-clearance rate of $69 \%$ in one year with a $40.7 \%$ reduction in antigenaemia.

A reduction in microfilaria density by $74-80 \%$ and a $19-28 \%$ microfilaria clearance rate at 1 year after treatment.

Microfilaria clearance achieved in $78 \%$ of infected people. However, $76.1 \%$ of them remained positive for the $\mathrm{Og} 4 \mathrm{C} 3$ antigen at end of 17 months.

Only $57 \%$ and $18 \%$ tested negative for microfilaria and antigenaemia, respectively at the end of the followup period of 10 years.

DEC $6 \mathrm{mg} / \mathrm{kg}$ for 12 days at $0,6,12,18$ months

Randomized

Beach et al.

1999 placebo-controlled clinical trial four arms

(i) IVM $200-400 \mu \mathrm{g} / \mathrm{kg}$ single dose

(ii) ALB $400 \mathrm{mg}$ single dose

(iii) Combination of both

(iv) Placebo

Richards et al.

2005

Prospective

entomological survey

Double-blind

Dunyo et al. (i) IVM 150-200 $\mu \mathrm{g} / \mathrm{kg}$ single dose (ii) IVM 150-200 $\mu \mathrm{g} / \mathrm{kg}+$ ALB $400 \mathrm{mg}$ single dose
Only $12 \%$ clearance rate of antigenaemia at the end of a followup period of 2 years.

Combined therapy with ALB and IVM reduces microfilaraemia more than placebo or individual drugs

The combination of ALB and IVM appears to be superior to IVM alone for reducing the frequency of $W$. bancrofti infection in mosquitoes.

Both IVM and combination treatment appeared effective for control of $W$. bancrofti infections, but the difference in efficacy between the 2 treatments after 12 months appeared to be minimal. 
Table 1: Continued.

\begin{tabular}{|c|c|c|c|c|}
\hline Authors & Year & Study design & Drug doses & Outcome \\
\hline Ismail et al. & 1996 & $\begin{array}{l}\text { Double-blind clinical } \\
\text { trial two arms }\end{array}$ & $\begin{array}{l}\text { (i) } 400 \mu \mathrm{g} / \mathrm{kg} \text { of IVM } 12 \text { fortnightly } \\
\text { doses } \\
\text { (ii) } 10 \mathrm{mg} / \mathrm{kg} \text { of DEC } 12 \text { fortnightly } \\
\text { doses }\end{array}$ & $\begin{array}{l}\text { IVM has higher microfilarial (mf) } \\
\text { clearance, and DEC has higher } \\
\text { antigenaemia (ag) clearance. Both } \\
\text { therapies had residual mf and ag levels } \\
\text { comparable with each other following } 1 \\
\text { and } 3 \text { months of dosing, respectively. }\end{array}$ \\
\hline Ismail et al. & 1998 & $\begin{array}{l}\text { Blinded four-arm } \\
\text { clinical trial }\end{array}$ & $\begin{array}{l}\text { (i) ALB } 600 \mathrm{mg} \text { single dose } \\
\text { (ii) ALB } 600 \mathrm{mg}+\text { IVM } 400 \mu \mathrm{g} / \mathrm{kg} \\
\text { (iii) ALB } 600 \mathrm{mg}+\text { DEC } 6 \mathrm{mg} / \mathrm{kg} \\
\text { (iv) IVM } 400 \mu \mathrm{g} / \mathrm{kg}+\text { DEC } 6 \mathrm{mg} / \mathrm{kg}\end{array}$ & $\begin{array}{l}\text { All } 4 \text { treatments significantly reduced mf } \\
\text { counts, but ALB/IVM was the most } \\
\text { effective regimen for clearing mf from } \\
\text { night blood. All } 4 \text { treatments had } \\
\text { significant activity against adult } W \text {. } \\
\text { bancrofti with DEC+ALB having the } \\
\text { greatest effect (Followup: } 15 \text { months). }\end{array}$ \\
\hline Ismail et al. & 2001 & $\begin{array}{l}\text { Blinded three-arm } \\
\text { clinical trial }\end{array}$ & $\begin{array}{l}\text { (i) ALB } 400 \mathrm{mg}+\text { IVM } 200 \mu \mathrm{g} / \mathrm{kg} \\
\text { (ii) ALB } 400 \mathrm{mg}+\text { DEC } 6 \mathrm{mg} / \mathrm{kg} \\
\text { (iii) ALB } 600 \mathrm{mg}+\text { IVM } 400 \mu \mathrm{g} / \mathrm{kg}\end{array}$ & $\begin{array}{l}\text { All } 3 \text { treatments significantly reduced mf } \\
\text { counts, with the ALB-DEC-treated group } \\
\text { showing the lowest mf levels at } 18 \text { and } 24 \\
\text { months after-treatment. All } 3 \text { treatments } \\
\text { had significant activity against adult } W \text {. } \\
\text { bancrofti; ALB-DEC combination had the } \\
\text { greatest activity. }\end{array}$ \\
\hline Makunde et al. & 2003 & $\begin{array}{l}\text { Crossover, } \\
\text { double-blind design } \\
\text { two groups }\end{array}$ & $\begin{array}{l}\text { For group with coinfection with } W \text {. } \\
\text { bancrofti and } O \text {. volvulus-single dose of } \\
\text { IVM } 150 \mu \mathrm{g} / \mathrm{kg}+400 \mathrm{mg} \text { ALB versus } \\
\text { placebo. Treatment was crossed over } \\
\text { after } 5 \text { days of initial dosing } \\
\text { For group with only } W \text {. bancrofti } \\
\text { infection-Single dose of ALB } 400 \mathrm{mg} \\
\text { versus ALB+IVM } 150 \mu \mathrm{g} / \mathrm{kg}\end{array}$ & $\begin{array}{l}\text { There was no significant difference in the } \\
\text { reduction of microfilaraemia following } \\
\text { treatment with ALB and IVM in groups } \\
\text { with single or coinfection. IVM plus ALB } \\
\text { is a safe and tolerable treatment for } \\
\text { coinfection of bancroftian filariasis and } \\
\text { onchocerciasis. }\end{array}$ \\
\hline Stolk et al. & 2005 & $\begin{array}{l}\text { Prospective two-arm } \\
\text { study two arms }\end{array}$ & $\begin{array}{l}\text { (i) } 400 \mu \mathrm{g} / \mathrm{kg} \text { IVM single dose } \\
\text { (ii) } 6 \mathrm{mg} / \mathrm{kg} \text { DEC single dose }\end{array}$ & $\begin{array}{l}\text { IVM on average killed } 96 \% \text { of Mf and } \\
\text { reduced Mf production by } 82 \% \text {. DEC } \\
\text { killed } 57 \% \text { of Mf and reduced Mf } \\
\text { production by } 67 \% \text {. }\end{array}$ \\
\hline Reddy et al. & 2000 & $\begin{array}{l}\text { Double-blind } \\
\text { two-arm clinical trial }\end{array}$ & $\begin{array}{l}\text { (i) } 400 \mu \mathrm{g} / \mathrm{kg} \text { IVM single dose } \\
\text { (ii) } 6 \mathrm{mg} / \mathrm{kg} \text { DEC single dose }\end{array}$ & $\begin{array}{l}\text { Tolerability and efficacy of the two drugs } \\
\text { (IVM, DEC) were not significantly } \\
\text { different between gender, age, and weight } \\
\text { classes of patients at two years. }\end{array}$ \\
\hline Debra et al. & 2006 & $\begin{array}{l}\text { Double-blind } \\
\text { placebo-controlled } \\
\text { trial }\end{array}$ & $\begin{array}{l}\text { Doxycycline } 200 \mathrm{mg} / \mathrm{d} \text { for } 6 \text { weeks } \\
\text { followed by IVM } 150 \mu \mathrm{g} / \mathrm{kg}+400 \mathrm{mg} \\
\text { ALB single dose } 4 \text { months later }\end{array}$ & $\begin{array}{l}\text { Wolbachia load, microfilaraemia, } \\
\text { antigenaemia, and frequency of filarial } \\
\text { dance sign were significantly reduced in } \\
\text { microfilaraemic patients up to } 24 \text { months } \\
\text { in the doxycycline group compared to the } \\
\text { placebo group. }\end{array}$ \\
\hline Debra et al. & 2009 & $\begin{array}{l}\text { Double-blind } \\
\text { placebo-controlled } \\
\text { trial }\end{array}$ & $\begin{array}{l}\text { Doxycycline } 200 \mathrm{mg} / \mathrm{d} \text { for } 6 \text { weeks } \\
\text { followed by IVM } 150 \mu \mathrm{g} / \mathrm{kg}+400 \mathrm{mg} \\
\text { ALB single dose } 4 \text { months later }\end{array}$ & $\begin{array}{l}\text { Six-week regimen of doxycycline treatment } \\
\text { showed improvement of clinical features of } \\
\text { hydrocoele patients with active infection. }\end{array}$ \\
\hline Taylor et al. & 2005 & $\begin{array}{l}\text { Double-blind } \\
\text { placebo-controlled } \\
\text { randomized trial }\end{array}$ & Doxycycline $200 \mathrm{mg} / \mathrm{d}$ for 8 weeks & $\begin{array}{l}\text { An } 8 \text {-week course of doxycycline is a safe } \\
\text { and well-tolerated treatment for lymphatic } \\
\text { filariasis with significant activity against } \\
\text { adult worms and microfilaraemia. }\end{array}$ \\
\hline
\end{tabular}

response at one year. IVM is avoided in areas endemic for Loa loa $[23,24]$.

4.2. Single Dose versus Combination Therapy. There are several studies comparing single drug therapy with combination therapy. Dreyer et al. [25] report a significant reduction in macrofilaricidal effect in the combined regime of DEC and ALB compared to DEC alone $(P=.016)$ with no additional effect on microfilaria reduction rates. In a large randomized controlled clinical trial, Bockarie et al. 
[26] demonstrated that single dose DEC (6 mg/Kg of body weight) has no superiority over combination therapy (DEC with ALB $400 \mathrm{mg}$ single dose) in reducing microfilaria rates over a followup period of 2 years. Nonetheless, combination therapy had a significant macrofilaricidal effect $(P<.003)$ compared to DEC alone at the end of followup (the antigen $\mathrm{Og} 4 \mathrm{C} 3$ prevalence was used to measure adult worm activity). Fox et al. [27], in a large scale $(n=990)$ randomized placebo-controlled trial, showed that combination therapy has a significant microfilaricidal effect compared to DEC or ALB used alone $(P<.03)$. In a smaller prospective study, Hussein et al. [28] $(n=58)$ demonstrated that ultrasonographic evidence of adult worm nests showed a $90 \%$ reduction after 1 year from start of combination therapy with DEC+ALB. It was also shown that single dose therapy versus multiple doses (over 7 days) had no additional benefit in this regard. Conflicting evidence comes from El Setouhy et al. [29] who report significantly greater microfilaricidal and macrofilaricidal effects at 1 year for multiple doses of combined therapy with ALB+DEC.

IVM is usually administered in combination with ALB. Two studies have shown that the combination is more effective in killing microfilaria in humans and reducing infection rates in the vector than individual drugs or placebo $[30,31]$. There is some speculation that IVM affects the reproductive capacity of female worms [32]. Five clinical trials in Sri Lanka [33, 34], Ghana [35, 36], and Tanzania [37] with a followup for 1-2 years have demonstrated the efficacy of ALB and IVM combination on microfilaria clearance. Two studies $[33,34]$ had an arm treated with high-dose IVM $(400 \mu \mathrm{g} / \mathrm{Kg})$ and ALB (Table 1$)$. The Sri Lankan trials also compared the efficacy of IVM and ALB with DEC and ALB. Almost all regimens with IVM demonstrated a rapid kill rate of microfilaria with higher doses showing a greater reduction in microfilaria rates. A subsequent mathematicalmodel-based analysis based on these 5 trials has shown that the reduction of microfilaria with DEC and ALB is slower but long lasting [38]. While constructing the model, the authors have tried to assess the trends in microfilaria densities in several trials after starting treatment with different antifilarial drug combinations. Since the study populations were from endemic areas, it was assumed that before the start of treatment the microfilarial densities were at an equilibrium (production matched by elimination) and the effect of drugs were described in two terms; microfilaria loss (fraction of microfilaria killed) and worm productivity loss (fraction of microfilaria permanently rendered incapable of reproducing). As the maximum followup was 2 years in the studies entered into the model, new infections were thought not to affect the equilibrium as they would not yield microfilaria during this period due to the long premature period of the worm. By using this model authors have also tried to estimate how the microfilarial densities would change in the posttreatment period. From observed data, DEC- and ALBbased trials had an almost $100 \%$ worm productivity loss at both high and low doses of ALB while only the high-dose combinations of IVM and ALB recorded similar results. Even after allowing for acquisition of new infections, the efficacy estimates did not vary between the trial arms. Ismail et al.
[33] recommend that ALB and DEC are a better option for mass chemotherapy for endemic populations, based on the high rates of microfilarial clearance.

Bockarie et al. [39-41], in a prospective study, recruited nearly 2500 people to receive four rounds of annual treatment in Papua New Guinea. They were randomly assigned to two treatment groups to receive either DEC and IVM or DEC alone. After four rounds of treatment (77\%-86\% compliance rate), microfilaria positive infections were reduced by $86-$ $98 \%$. Chronic manifestations such as lymphoedema and hydrocoele were also significantly reduced in the population $(P=.04,<.001$, resp. $)$. There was no difference in the two drug regimens with regard to efficacy. However, the combination of IVM and DEC rapidly reduced microfilaria positivity, especially in high-transmission areas. Still, at the end of the four years, the odds of microfilaria transmission were the same for both regimens.

A double-blind clinical trial on a head-to-head comparison of high-dose IVM and DEC showed that IVM has a higher microfilarial clearance and DEC has a higher antigenaemia clearance [42]. Both therapies had residual microfilaria and $\mathrm{Ag}$ levels comparable with each other following 1 and 3 months of dosing, respectively.

4.3. Treating the Masses: Evidence from Mass Treatment Programmes. In 1997, WHO drew the blueprint to eliminate lymphatic filariasis by 2020 [1]. Mass drug administration (MDA) in endemic areas/countries was considered to be more cost effective than detecting and treating infected individuals. The low side effect profile of drugs and the pledge by two pharmaceutical companies to provide them free of charge, as long as necessary, made MDA a good elimination strategy. Currently, an estimated 754 million people in 81 countries are targeted for MDA and 546 million are already receiving it. Sixty-one countries have completed mapping of endemic areas, and in another 16 it is in progress. China and South Korea have already declared the elimination of lymphatic filariasis as a public health priority [43]. The use of MDA in filariasis gives the unique opportunity to see how the results of smaller clinical trials are valid when the drugs are administered to masses of general population. Currently there are three regimens approved for MDA, namely, DEC with ALB, IVM with ALB, and DEC- medicated salt [43].

In Burkina Faso, MDA with IVM alone (for onchocerciasis) has shown an indirect benefit by lowering W. bancrofti microfilaria rates. Kyelem et al. [44] reported that, in comparison to nonendemic and, therefore, nontreated communities, the treated communities had significantly lower microfilaria rates after six rounds of annual treatment. However, the rates of hydroceles and lymphoedema did not differ in the two communities. Furthermore, an entomological survey by Richards et al. [45] did not find significantly lower rates of infection in mosquitoes with $W$. bancrofti larvae in treated and untreated communities with IVM in Nigeria (MDA for onchocerciasis). All communities had good compliance with MDA, but only two rounds of treatment were completed in three of the five communities 
TABLE 2: Summary of followup studies on cohorts receiving mass drug administration.

\begin{tabular}{|c|c|c|c|c|c|}
\hline Author & $\begin{array}{c}\text { Year } \\
\text { published }\end{array}$ & Design & Drug regimen & Followup & Conclusions \\
\hline $\begin{array}{l}\text { Bockarie et al., } \\
\text { Papua New } \\
\text { Guinea }\end{array}$ & 2002 & $\begin{array}{l}\text { Prospective } \\
\text { controlled } \\
\text { randomized } \\
\text { clinical trial }\end{array}$ & $\begin{array}{l}\text { (i) DEC } 6 \mathrm{mg} / \mathrm{kg} \text { single dose } \\
\text { (ii) DEC } 6 \mathrm{mg} / \mathrm{kg}+\text { IVM } \\
\text { single dose }\end{array}$ & 5 years & $\begin{array}{l}\text { Microfilaria positive infections were } \\
\text { reduced by } 86 \%-98 \% \text {. Chronic } \\
\text { manifestations such as lymphoedema and } \\
\text { hydrocoele were also significantly } \\
\text { reduced in the population. No difference } \\
\text { in two regimens at end of followup. }\end{array}$ \\
\hline $\begin{array}{l}\text { Kyelem et al., } \\
\text { Burkina faso }\end{array}$ & 2003 & $\begin{array}{l}\text { Prospective } \\
\text { two-arm study }\end{array}$ & $\begin{array}{l}\text { Communities receiving } \\
\text { IVM } 150 \mu \mathrm{g} / \mathrm{kg} \text { annually } \\
\text { compared with } \\
\text { communities not receiving } \\
\text { MDA }\end{array}$ & 6 years & $\begin{array}{l}\text { Long-term IVM (given for } \\
\text { onchocerciasis) significantly reduced } W \text {. } \\
\text { bancrofti and } M \text {. perstans } \\
\text { microfilaraemia. }\end{array}$ \\
\hline $\begin{array}{l}\text { Richards et al., } \\
\text { Nigeria }\end{array}$ & 2005 & $\begin{array}{l}\text { Cross-sectional } \\
\text { entomological } \\
\text { survey }\end{array}$ & $\begin{array}{l}\text { Communities receiving } \\
\text { IVM } 150 \mu \mathrm{g} / \mathrm{kg} \text { annually }\end{array}$ & $\begin{array}{l}2-3 \text { annual } \\
\text { rounds of } \\
\text { chemotherapy } \\
\text { completed }\end{array}$ & $\begin{array}{l}\text { Annual therapy with IVM for } \\
\text { onchocerciasis has not interrupted } \\
\text { transmission of Wuchereria bancrofti. }\end{array}$ \\
\hline Ramaiah et al., & 2007 & $\begin{array}{l}\text { Community-based } \\
\text { followup study } \\
\text { with two arms }\end{array}$ & $\begin{array}{l}\text { DEC } 6 \mathrm{mg} / \mathrm{kg} \text {, single dose } \\
\text { annual therapy versus IVM } \\
400 \mu \mathrm{g} / \mathrm{kg} \text { single dose } \\
\text { annual therapy }\end{array}$ & 10 years & $\begin{array}{l}\text { DEC had the potential to interrupt } \\
\text { transmission while the capability of IVM } \\
\text { to do so was less. }\end{array}$ \\
\hline Liang et al., & 2008 & Followup study & $\begin{array}{l}\mathrm{DEC}+\mathrm{ALB} \text { standard } \\
\text { dosing }\end{array}$ & 6 years & $\begin{array}{l}\text { The antigenaemia prevalence dropped } \\
\text { from } 11.5 \% \text { in } 2001 \text { to } 0.95 \% \text { in } 2006 \\
(P<.0001) \text {. }\end{array}$ \\
\hline $\begin{array}{l}\text { Mataika et al., } \\
\text { Fiji }\end{array}$ & 1995 & Followup study & $\begin{array}{l}\text { Annual single dosing of } \\
\text { DEC } 6 \mathrm{mg} / \mathrm{kg}\end{array}$ & 5 years & $\begin{array}{l}\text { MDA with DEC alone led to a statistically } \\
\text { significant reduction in microfilaria rates } \\
\text { irrespective of the pretreatment mf rates. }\end{array}$ \\
\hline $\begin{array}{l}\text { Freeman et al., } \\
\text { Haiti }\end{array}$ & 2001 & $\begin{array}{l}\text { community-based } \\
\text { trial }\end{array}$ & DEC medicated salt & 1 year & $\begin{array}{l}\text { DEC and Iodine fortified salt lowered the } \\
\text { prevalence and intensity of } \\
\text { microfilaraemia by } 95 \% \text {. Impact on adult } \\
\text { worms was less. }\end{array}$ \\
\hline
\end{tabular}

Comparison of four strategies of community treatment with DEC $6 \mathrm{mg} / \mathrm{kg}$

Meyrowitsch et 1996 community-based (i) 12 day regimen al., Tanzania

(ii) Semiannual single dose treatment

(iii) Monthly low dose regimen

(iv) DEC medicated salt

Meyrowitsch et al., Tanzania

community-based trial

Followup of above-study

Fan et al., China

1990

Community-based trial

DEC medicated salt

Liu et al., China

1992

Community-based trial

DEC medicated salt

Group A: MDA with

Sunish et al., India

Community-based annual single dose of IVM $400 \mu \mathrm{g} / \mathrm{kg}+$ DEC $6 \mathrm{mg} / \mathrm{kg}$ Group B: MDA with vector control Group C-Placebo
10 years

12 years

4 years

Strategies III and IV were equally effective, and superior in clearing microfilaraemias and in reducing $\mathrm{mf}$ geometric mean intensities compared to strategies I and II.

Microfilaria rates were reaching pretreatment values in all communities.

Microfilaria rates and infection rates were reduced from $9.6 \%$ to $0.3 \%$ and $9.1 \%$ to $0.8 \%$, respectively.

Microfilaria rates dropped from a range of $1.56-11.81 \%$ to $0.05 \%$ in the communities studied.

3-4 years

The improvement with MDA was sustained in the second group while resurgence occurred in the first group. 
TABle 2: Continued.

\begin{tabular}{|c|c|c|c|c|c|}
\hline Author & $\begin{array}{c}\text { Year } \\
\text { published }\end{array}$ & Design & Drug regimen & Followup & Conclusions \\
\hline $\begin{array}{l}\text { Simonsen et al., } \\
\text { Eastern Africa }\end{array}$ & 2004 & $\begin{array}{l}\text { Community-based } \\
\text { trial in } \\
\text { high-endemicity } \\
\text { and } \\
\text { low-endemicity } \\
\text { communities }\end{array}$ & $\begin{array}{l}\text { Semiannual treatment with } \\
\text { DEC } 6 \mathrm{mg} / \mathrm{kg}\end{array}$ & 1 year & $\begin{array}{l}\text { Transmission rates dropped only in high } \\
\text { endemicity communities, but it cannot } \\
\text { be entirely attributed to MDA. }\end{array}$ \\
\hline Esterre et al., & 2001 & $\begin{array}{l}\text { Community-based } \\
\text { followup study }\end{array}$ & $\begin{array}{l}\text { Semiannual treatment with } \\
\text { DEC } 6 \mathrm{mg} / \mathrm{kg} \text { for more } \\
\text { than } 30 \text { years }\end{array}$ & 34 years & $\begin{array}{l}\text { Microfilaria and antigenaemia rates were } \\
\text { very low but not zero. }\end{array}$ \\
\hline
\end{tabular}

studied. A community-based trial on head to head comparison on the efficacy of DEC $(6 \mathrm{mg} / \mathrm{kg}$, single dose $)$ and IVM $(400 \mu \mathrm{g} / \mathrm{kg}$, single dose) in South India has shown that after 10 years of annual MDA, DEC had the potential to interrupt the transmission of filariasis while IVM was less able to do so [46].

ALB and DEC are used as a combination for MDA in many nononchocerciasis-endemic populations, and has been proven to be effective. After 6 years of MDA in American Samoa, the antigenaemia prevalence dropped from $11.5 \%$ in 2001 to $0.95 \%$ in $2006(P<.0001)$ with this regimen [47]. MDA for five years with DEC alone in Fiji has also shown a statistically significant reduction in microfilaria rates irrespective of the pretreatment microfilaria rates [48].

4.4. The Role of DEC-Fortified Salt. DEC-medicated cooking salt has been used to facilitate mass treatment and has proved to be very effective and safe. DEC fortified salt has been recommended mainly for control programmes chiefly because of its ability to clear microfilaraemias without causing adverse reactions. It is anticipated that this approach would ensure compliance. The lack of adverse effects is due to the very slow clearance of parasitaemia compared with that achieved with tablets. DEC medicated salt plays a major role in the Chinese filariasis control programme and proved successful in more limited trials in India, Brazil, and Tanzania [49-52]. It has been shown that DEC salt is more effective than single dose DEC in reducing the prevalence of microfilaraemia. DEC fortified salt may be useful in areas where the mobilisation of the population for annual drug distribution is difficult. Common salt medicated with 1$3 \mathrm{~g}$ of DEC per $\mathrm{kg}$ is used for atleast $6-12$ months. It is well tolerated and safe to use in pregnancy. It is colourless, odourless, thermostable, and tastes the same as ordinary cooking salts. The macrofilaricidal effect of very low-dose DEC as used in the DEC medicated salt is not sure. Low dose DEC in salt minimizes or avoids completely the known side effects of treatment, including both acute pharmacologic effects of high doses and Mazzotti-like inflammatory reactions (probably due to dying microfilariae) induced by moderate and high doses [53].

Several pilot studies have been conducted using salt fortified with DEC in endemic communities in India,
Tanzania, and Brazil. All of them have demonstrated effective microfilaria kill rates $[49,51,52,54-56]$. A large communitybased trial in Haiti, over a period of 1 year has shown that DEC- and Iodine-fortified salt lowered the prevalence and intensity of microfilaraemia by $95 \%$ [57]. However, the impact on adult worms was less $(60 \%$ reduction in $\mathrm{Og} 4 \mathrm{C} 3$ antigenaemia and a nonsignificant reduction in motility of worm nests detected by ultrasound).

\section{Resurgence after MDA: Is Eradication Possible?}

WHO aims to achieve cessation of transmission of infection after 4-6 rounds of therapy yearly (which corresponds to the fecundity of the adult worms) provided the compliance is good. However, initial small-scale trials failed to completely clear microfilaria rates with either combination of drugs, though the ALB+DEC combination had a lasting effect. The followup studies after several MDA rounds confirm this. Meyrowitsch et al. [58] report that after 10 years of MDA with DEC (given in three regimens) the microfilaria levels were reaching the pretreatment value in all communities. Many of the recurrences were in previously microfilaria positive individuals indicating the possibility of reproduction from surviving female adults. A three-arm communitybased trial in India assessed the impact of two rounds of annual MDA after 3 years since the last dosing. The improvement with MDA was sustained when therapy was combined with vector control $[59,60]$. The importance of vector control and understanding of local transmission dynamics are also underscored by Simonsen et al. [61], who have shown that after two rounds of MDA, mosquitoes carrying infective larvae were not reduced, though $\mathrm{mf}$ rates in the community were significantly less. The most suitable cohort to study the impact of long-term MDA is the Maupiti cohort of French Polynesia where semiannual MDA has been combined with vector control since 1955 . Two surveys in 1985 and 1989 showed a 0\% microfilaria rate which gave hope that eradication was complete. Nonetheless, Esterre et al. [62] in two repeated cross-sectional analyses in 1997 and 1999 have shown residual microfilaraemia and antigenaemia $(0.4 \%$ and $4.6 \%$, resp. $)$ with a $1.4 \%$ infectivity rate in vector population. There are several plausible explanations for this 
observation: efficiency of the vector, resistance to DEC, and prolonged longevity of adult worms. These findings cast doubt on the possibility of a complete "eradication" of filariasis with MDA.

In this background, Micheal et al. [63, 64] suggest that plans to control lymphatic filariasis should be more pragmatic, flexible, economically sensitive, and sequential. They suggest that the first target in an elimination programme should be to achieve an infection rate at which chronic manifestations of infection (causing more productivity loss and DALYs) become negligible despite ongoing infection. Using a mathematical model based on available data it is suggested that a microfilaria rate of $3.55 \%$ at a blood sampling volume of $1 \mathrm{ml}$ will achieve this. This target is both achievable and sustainable with current MDA regimens.

\section{Resistance to Drugs}

One factor linked to resurgence of infection following MDA is the resistance to drugs. It is impossible to assess the resistance to DEC as its mechanism of action is still obscure. However, resistance to IVM and ALB has been reported in nematodes in veterinary practice. In 2004, resistance to IVM was reported in the human parasite Oncocerca volvulus [65]. There are yet no confirmed reports of resistance in $W$. bancrofti for IVM.

The main cause for concern, however, is resistance to Benzimidazoles (BZ), namely, ALB. The resistance to BZs (ALB, Mebendazole) is seen in many nematode parasites due to single nucleotide polymorphisms (SNP) [66]. Two SNPs substituting tyrosine for phenylalanine of the $\beta$ tubulin protein of nematodes confer resistance to ALB in veterinary practice. Schwab et al. $[67,68]$ has demonstrated that similar SNPs exist in $W$. bancrofti in untreated populations, and such mutations are selected for after mass treatment. The impact of this may not be felt immediately in the population as microfilarial rates drop rapidly with combined chemotherapy. Still, if resurgence occurs in future, resistant genotypes with a selection advantage may predominate in the parasite population making ALB resistance a significant problem. However, as some authors point out, the real problem is not related to $W$. bancrofti at all it is the possibility of other intestinal nematodes developing resistance to BZs due to large scale exposure to ALB during MDA that could pose a serious threat to health of children and adults in endemic areas [69].

\section{The Place for Targeting Wolbachia with Doxycycline in Treatment Regimens}

Wolbachia is an intracellular symbiotic bacterium of filarial parasites. It plays an essential role in larval moulting, adult worm survival, and female worm fertility. Killing the bacterium with doxycycline has shown promise in many studies by reducing adult worm activity $[70,71]$. Though doxycycline therapy has been experimented with for treating infections with other filarial worms, the first trial with regard to W. Bancrofti was conducted in 2005 by Taylor et al. [72] after 8 weeks of doxycycline $200 \mathrm{mg} / \mathrm{d}$, microfilaraemia was almost eliminated $(P<.001)$, antigenaemia was halved $(P=.015)$, and ultrasonographically demonstrated adult worm activity was significantly less $(P<.0001)$ in the treatment group versus placebo group (after 14 months of followup). There were no serious side effects with treatment. Subsequent studies with shorter courses of doxycycline (6, and 4 weeks, resp.) have shown a similar effect. In these studies antibacterial therapy was followed up with IVM+ALB combined therapy $[73,74]$. However, a 3-week course of the drug failed to show an adequate macrofilaricidal effect [75].

In addition to killing the endosymbionts and reducing the filarial worm load, doxycycline also improves clinical manifestations of filariasis. The levels of vascular endothelial growth factor C (VEGF-C) and soluble vascular endothelial growth factor receptor-3 [(s)VEGFR-3], which has been shown to be important in pathogenesis of filariasis in animal models, were lowered in test subjects following doxycycline therapy [76]. The macrofilaricidal effect of doxycycline is slow compared to DEC, and the side effects seen after DEC treatment (abscesses, etc.) are not seen. Addition of doxycycline to treatment regimens will have a beneficial effect especially in Onchocercaria endemic areas where DEC is contraindicated. IVM used in these areas have no or minimum macrofilaricidal effect.

\section{Limitations}

This review was limited to articles published in English within 1999-2009 time period. While attempts were made to search related literature as well, it is possible that important studies published in other languages and outside the search limits were missed.

\section{Conclusions}

WHO has outlined two objectives for its campaign of MDA: to interrupt transmission and to reduce morbidity of disease [1]. The best combination of drugs for an MDA programme was still not clarified by the time the programmes were launched in endemic areas. Clearly, one of the main difficulties in determining the efficacy of individual drugs is that different endpoints have been used in different trials (microfilaria-clearance rates, antigenaemia-clearance rates etc.), and correlating efficacy based on these endpoints and actual clinical efficacy is difficult. As individual drugs, IVM reduced the microfilaria rates rapidly, but DEC had more macrofilaricidal effects with a higher clearance of antigenaemia. The only available large-scale community-based trial to evaluate IVM versus DEC, showed that the latter was more effective in interrupting transmission [46]. The evidence for benefits of combination therapy is also conflicting but many studies favour it. Only two studies quoted above show no difference between single and combination therapy while Dreyer et al. [25] actually report a loss in macrofilaricidal effect of DEC when given in combination. However, this study uses ultrasound evidence to assess outcome rather than the antigen clearance. It may be difficult to correlate 
antigenaemia to macrofilaricidal effects as shown by a large scale study in Sri Lanka. After a 12-day course of DEC, 78\% showed microfilaria clearance. However, of $76 \%$ of those "cured" parasitologically were still positive for the Og4C3 antigen at 17 months [77]. The ALB+DEC regimen was considered a better option for nononchocercaria endemic areas than the ALB+IVM regimen. Nonetheless, large-scale randomized clinical trials are not available to formulate evidence-based guidelines for chemotherapy, and currently only recommendations can be made in treating bancroftian filariasis based on available evidence.

Despite 50 years of research into filariasis control, still many questions remain unanswered. These include basic issues like mechanism of action of DEC, best combination of drugs for elimination strategies, and evidence-based recommendations to treat lymphatic filariasis. Differences in the end-points of treatment studied add confusion to the benefits of the different drugs and drug combinations. Much of the recommendations for therapy are based on microfilaraemia and antigenaemic clearance; evidence of reduction of clinical manifestations has not been studied adequately in either large-scale population surveys or clinical studies. The need to identify clear endpoints in future clinical trials and population surveys cannot be overemphasised. The policies of MDA also need to be reviewed, and, as community-based studies have shown, despite intensive therapy, that infection rates have not been reduced to zero. It is important to combine vector control with MDA and develop elimination strategies that are flexible and achievable in local context. Perhaps it is more important to target an infection rate that reduces the impact of lymphatic filariasis as a public health problem rather than aim towards total eradication, as eventually what matters is that the clinical manifestations of lymphatic filariasis are prevented.

\section{References}

[1] WHO, "Lymphatic filariasis," Geneva, Switzerland, June 2009, http://www.who.int/mediacentre/factsheets/fs102/en/.

[2] G. Chandra, "Nature limits filarial transmission," Parasites and Vectors, vol. 1, no. 1, article 13, 2008.

[3] GAELF, “Clinical features," June 2009, http://www.filariasis. org/all_about_lf/disease.html\#clinicalfeatures.

[4] V. K. Vijayan, "Tropical pulmonary eosinophilia: pathogenesis, diagnosis and management," Current Opinion in Pulmonary Medicine, vol. 13, no. 5, pp. 428-433, 2007.

[5] K. D. Ramaiah, H. Guyatt, K. Ramu, P. Vanamail, S. P. Pani, and P. K. Das, "Treatment costs and loss of work time to individuals with chronic lymphatic filariasis in rural communities in south India," Tropical Medicine and International Health, vol. 4, no. 1, pp. 19-25, 1999.

[6] K. D. Ramaiah, K. Ramu, H. Guyatt, K. N. Vijar Kumar, and S. P. Pani, "Direct and indirect costs of the acute form of lymphatic filariasis to households in rural areas of tamil nadu, south india," Tropical Medicine and International Health, vol. 3, no. 2, pp. 108-115, 1998.

[7] P. Johnson, C. D. Mackenzie, D. A. Denham, and R. R. Suswillo, "The effect of diethylcarbamazine on the in vitro serum-mediated adherence of feline granulocytes to microfilariae of Brugia pahangi," Tropical Medicine and Parasitology, vol. 39, no. 4, pp. 291-294, 1988.

[8] N. Kanesa-thasan, J. G. Douglas, and J. W. Kazura, "Diethylcarbamazine inhibits endothelial and microfilarial prostanoid metabolism in vitro," Molecular and Biochemical Parasitology, vol. 49, no. 1, pp. 11-20, 1991.

[9] C. A. Peixoto, A. C. O. Santos, and C. F. J. Ayres, "Molecular evidence for apoptosis in microfilariae of Wuchereria bancrofti induced by diethylcarbamazine," Parasitology Research, vol. 103, no. 3, pp. 717-721, 2008.

[10] E. A. Ottesen, "Efficacy of diethylcarbamazine in eradicating infection with lymphatic-dwelling filariae in humans," Reviews of Infectious Diseases, vol. 7, no. 3, pp. 341-356, 1985.

[11] M. Abramowicz, M. A. Rizack, D. Goodstein, A. Faucard, P. D. Hansten, and N. H. Steigbigel, "Drugs for parasitic infections," Medical Letter on Drugs and Therapeutics, vol. 40, no. 1017, pp. $1-12,1998$.

[12] D. Addiss and G. Dreyer, "Treatment of lymphatic filariasis," in Lymphatic Filariasis, T. B. Nutman, Ed., pp. 103-125, Imperial College Press, London, UK, 2000.

[13] A. P. Oomen, "Fatalities after treatment of onchocerciasis with diethylcarbamazine," Transactions of the Royal Society of Tropical Medicine and Hygiene, vol. 63, no. 4, p. 548, 1969.

[14] A. C. Bird, H. El-Sheikh, J. Anderson, and H. Fuglsang, "Visual loss during oral diethylcarbamazine treatment for onchocerciasis," Lancet, vol. 2, no. 8132, p. 46, 1979.

[15] L. D. Andrade, Z. Medeiros, M. L. Pires et al., "Comparative efficacy of three different diethylcarbamazine regimens in lymphatic filariasis," Transactions of the Royal Society of Tropical Medicine and Hygiene, vol. 89, no. 3, pp. 319-321, 1995.

[16] R. M. R. Ramzy, M. El Setouhy, H. Helmy et al., "The impact of single-dose diethylcarbamazine treatment of bancroftian filariasis in a low-endemicity setting in Egypt," American Journal of Tropical Medicine and Hygiene, vol. 67, no. 2, pp. 196-200, 2002.

[17] M. V. Weerasooriya, E. Kimura, D. A. Dayaratna, T. R. Weerasooriya, and W. A. Samarawickrema, "Efficacy of a single dose treatment of Wuchereria bancrofti microfilaria carriers with diethylcarbamazine in Matara, Sri Lanka," The Ceylon Medical Journal, vol. 43, no. 3, pp. 151-155, 1998.

[18] M. K. Beuria, M. S. Bal, N. N. Mandal, and M. K. Das, "Antigenemia at 10 years after diethylcarbamazine treatment of asymptomatic microfilaraemic individuals: marginal conversion to infection-free state," Parasite Immunology, vol. 24, no. 2, pp. 109-111, 2002.

[19] D. O. Freedman, D. Adam Plier, A. B. De Almeida, A. L. De Oliveira, J. Miranda, and C. Braga, "Effect of aggressive prolonged diethylcarbamazine therapy on circulating antigen levels in bancroftian filariasis," Tropical Medicine and International Health, vol. 6, no. 1, pp. 37-41, 2001.

[20] S. P. Pani, G. Subramanyam Reddy, L. K. Das et al., "Tolerability and efficacy of single dose albendazole, diethylcarbamazine citrate (DEC) or co-administration of albendazole with DEC in the clearance of Wuchereria bancrofti in asymptomatic microfilaraemic volunteers in Pondicherry, South India: a hospital-based study," Filaria Journal, vol. 1, no. 1, article 1, 2002.

[21] W. A. Stolk, G. J. Van Oortmarssen, S. P. Pani et al., "Effects of ivermectin and diethylcarbamazine on microfilariae and overall microfilaria production in bancroftian filariasis," American Journal of Tropical Medicine and Hygiene, vol. 73, no. 5, pp. 881-887, 2005. 
[22] G. S. Reddy, N. Vengatesvarlou, P. K. Das et al., "Tolerability and efficacy of single-dose diethyl carbamazine (DEC) or ivermectin in the clearance of Wuchereria bancrofti microfilaraemia in Pondicherry, South India," Tropical Medicine and International Health, vol. 5, no. 11, pp. 779-785, 2000.

[23] M. Ducorps, N. Gardon-Wendel, S. Ranque et al., "Secondary effects of the treatment of hypermicrofilaremic loiasis using ivermectinEffets secondaires du traitement de la loase hypermicrofilarémique par l'ivermectine," Bulletin de la Société de Pathologie Exotique, vol. 88, no. 3, pp. 105-112, 1995.

[24] B. Carme, B. Ebikli, A. Mbitsi, and N. Copin, "Therapeutic trial with ivermectin against loiasis with medium and high microfilaremia," Annales de la Societe Belge de Medecine Tropicale, vol. 71, no. 1, pp. 47-50, 1991.

[25] G. Dreyer, D. Addiss, J. Williamson, and J. Norões, "Efficacy of co-administered diethylcarbamazine and albendazole against adult Wuchereria bancrofti," Transactions of the Royal Society of Tropical Medicine and Hygiene, vol. 100, no. 12, pp. 1118$1125,2006$.

[26] M. J. Bockarie, L. Tavul, I. Ibam et al., "Efficacy of singledose diethylcarbamazine compared with diethylcarbamazine combined with albendazole against Wuchereria bancrofti infection in Papua New Guinea," American Journal of Tropical Medicine and Hygiene, vol. 76, no. 1, pp. 62-67, 2007.

[27] L. M. Fox, B. W. Furness, J. K. Haser et al., "Tolerance and efficacy of combined diethylcarbamazine and albendazole for treatment of Wuchereria bancrofti and intestinal helminth infections in Haitian children," American Journal of Tropical Medicine and Hygiene, vol. 73, no. 1, pp. 115-121, 2005.

[28] O. Hussein, M. El Setouhy, E. S. Ahmed et al., "Duplex doppler sonographic assessment of the effects of diethylcarbamazine and albendazole therapy on adult filarial worms and adjacent host tissues in bancroftian filariasis," American Journal of Tropical Medicine and Hygiene, vol. 71, no. 4, pp. 471-477, 2004.

[29] M. El Setouhy, R. M. R. Ramzy, E. S. Ahmed et al., "A randomized clinical trial comparing single- and multi-dose combination therapy with diethylcarbamazine and albendazole for treatment of bancroftian filariasis," American Journal of Tropical Medicine and Hygiene, vol. 70, no. 2, pp. 191-196, 2004.

[30] M. J. Beach, T. G. Streit, D. G. Addiss, R. Prospere, J. M. Roberts, and P. J. Lammie, "Assessment of combined ivermectin and albendazole for treatment of intestinal helminth and Wuchereria bancrofti infections in Haitian schoolchildren," American Journal of Tropical Medicine and Hygiene, vol. 60, no. 3, pp. 479-486, 1999.

[31] F. O. Richards, D. D. Pam, A. Kal et al., "Significant decrease in the prevalence of Wuchereria bancrofti infection in anopheline mosquitoes following the addition of albendazole to annual, ivermectin-based, mass treatments in Nigeria," Annals of Tropical Medicine and Parasitology, vol. 99, no. 2, pp. 155164, 2005.

[32] W. A. Stolk, S. J. De Vlas, and J. D. F. Habbema, "AntiWolbachia treatment for lymphatic filariasis," Lancet, vol. 365, no. 9477, pp. 2067-2068, 2005.

[33] M. M. Ismail, R. L. Jayakody, G. J. Weil et al., "Long-term efficacy of single-dose combinations of albendazole, ivermectin and diethylcarbamazine for the treatment of bancroftian filariasis," Transactions of the Royal Society of Tropical Medicine and Hygiene, vol. 95, no. 3, pp. 332-335, 2001.

[34] M. M. Ismail, R. L. Jayakody, G. J. Weil et al., "Efficacy of single dose combinations of albendazole, ivermectin and diethylcarbamazine for the treatment of bancroftian filariasis,"
Transactions of the Royal Society of Tropical Medicine and Hygiene, vol. 92, no. 1, pp. 94-97, 1998.

[35] S. K. Dunyo, F. K. Nkrumah, and P. E. Simonsen, "Single-dose treatment of Wuchereria bancrofti infections with ivermectin and albendazole alone or in combination: evaluation of the potential for control at 12 months after treatment," Transactions of the Royal Society of Tropical Medicine and Hygiene, vol. 94, no. 4, pp. 437-443, 2000.

[36] S. K. Dunyo, F. K. Nkrumah, and P. E. Simonsen, "A randomized double-blind placebo-controlled field trial of ivermectin and albendazole alone and in combination for the treatment of lymphatic filariasis in Ghana," Transactions of the Royal Society of Tropical Medicine and Hygiene, vol. 94, no. 2, pp. 205-211, 2000.

[37] W. H. Makunde, L. M. Kamugisha, J. J. Massaga et al., "Treatment of co-infection with bancroftian filariasis and onchocerciasis: a safety and efficacy study of albendazole with ivermectin compared to treatment of single infection with bancroftian filariasis," Filaria Journal, vol. 2, no. 1, article 15, 2003.

[38] M. E. A. De Kraker, W. A. Stolk, G. J. Van Oortmarssen, and J. D. F. Habbema, "Model-based analysis of trial data: microfilaria and worm-productivity loss after diethylcarbamazinealbendazole or ivermectin-albendazole combination therapy against Wuchereria bancrofti," Tropical Medicine and International Health, vol. 11, no. 5, pp. 718-728, 2006.

[39] M. J. Bockarie, D. J. Tisch, W. Kastens et al., "Mass treatment to eliminate filariasis in Papua New Guinea," New England Journal of Medicine, vol. 347, no. 23, pp. 1841-1848, 2002.

[40] M. J. Bockarie, E. Ibam, N. D. E. Alexander et al., "Towards eliminating lymphatic filariasis in Papua New Guinea: impact of annual single-dose mass treatmnet on transmission of Wuchereria bancrofti in East Sepik Province," Papua and New Guinea Medical Journal, vol. 43, no. 3-4, pp. 172-182, 2000.

[41] D. J. Tisch, M. J. Bockarie, Z. Dimber et al., "Mass drug administration trial to eliminate lymphatic filariasis in Papua New Guinea: changes in microfilaremia, filarial antigen, and Bm14 antibody after cessation," American Journal of Tropical Medicine and Hygiene, vol. 78, no. 2, pp. 289-293, 2008.

[42] M. M. Ismail, G. J. Weil, K. S. A. Jayasinghe et al., "Prolonged clearance of microfilaraemia in patients with bancroftian filariasis after multiple high doses of ivermectin or diethylcarbamazine," Transactions of the Royal Society of Tropical Medicine and Hygiene, vol. 90, no. 6, pp. 684-688, 1996.

[43] GAELF, "Progressto date," June 2009, http://www.filariasis. org/all_about_lf/disease.html\#clinicalfeatures.

[44] D. Kyelem, S. Sanou, B. Boatin, J. Medlock, S. Coulibaly, and D. H. Molyneux, "Impact of long-term ivermectin (Mectizan) on Wuchereria bancrofti and Mansonella perstans infections in Burkina Faso: strategic and policy implications," Annals of Tropical Medicine and Parasitology, vol. 97, no. 8, pp. 827-838, 2003.

[45] F. O. Richards, A. Eigege, D. Pam et al., "Mass ivermectin treatment for onchocerciasis: lack of evidence for collateral impact on transmission of Wuchereria bancrofti in areas of coendemicity," Filaria Journal, vol. 4, article 6, 2005.

[46] K. D. Ramaiah, P. K. Das, P. Vanamail, and S. P. Pani, "Impact of 10 years of diethylcarbamazine and ivermectin mass administration on infection and transmission of lymphatic filariasis," Transactions of the Royal Society of Tropical Medicine and Hygiene, vol. 101, no. 6, pp. 555-563, 2007.

[47] J. L. Liang, J. D. King, K. Ichimori, T. Handzel, M. Pa'au, and P. J. Lammie, "Impact of five annual rounds of mass drug administration with diethylcarbamazine and albendazole 
on Wuchereria bancrofti infection in American Samoa," American Journal of Tropical Medicine and Hygiene, vol. 78, no. 6, pp. 924-928, 2008.

[48] J. U. Mataika, E. Kimura, J. Koroivueta, and M. Shimada, "Efficacy of five annual single doses of diethylcarbamazine for treatment of lymphatic filariasis in Fiji," Bulletin of the World Health Organization, vol. 76, no. 6, pp. 575-579, 1998.

[49] P. C. Fan, "Eradication of bancroftian filariasis by diethylcarbamazine-medicated common salt on Little Kinmen (Liehyu District), Kinmen (Quemoy) Islands, Republic of China," Annals of Tropical Medicine and Parasitology, vol. 84, no. 1, pp. 25-33, 1990.

[50] P. C. Fan, H. W. Peng, and C. C. Chen, "Follow-up investigations on clinical manifestations after filariasis eradication by diethylcarbamazine medicated common salt on Kinmen (Quemoy) Islands, Republic of China," Journal of Tropical Medicine and Hygiene, vol. 98, no. 6, pp. 461-464, 1995.

[51] D. W. Meyrowitsch, P. E. Simonsen, and W. H. Makunde, "Mass diethylcarbamazine chemotherapy for control of bancroftian filariasis through community participation: comparative efficacy of a low monthly dose and medicated salt," Transactions of the Royal Society of Tropical Medicine and Hygiene, vol. 90, no. 1, pp. 74-79, 1996.

[52] P. Krishnarao, R. Kaur, and T. K. Ghosh, "Long term effect of diethylcarbamazine medicated common salt on bancroftian filariasis," Journal of Communicable Diseases, vol. 23, no. 2, pp. 128-130, 1991.

[53] S. Adinarayanan, J. Critchley, P. K. Das, and H. Gelband, "Diethylcarbamazine (DEC)-medicated salt for communitybased control of lymphatic filariasis," Cochrane Database of Systematic Reviews, vol. 24, no. 1, Article ID CD003758, 2007.

[54] D. W. Meyrowitsch, P. E. Simonsen, and W. H. Makunde, "Mass DEC chemotherapy for control of bancroftian filariasis: comparative efficacy of four strategies two years after start of treatment," Transactions of the Royal Society of Tropical Medicine and Hygiene, vol. 90, no. 4, pp. 423-428, 1996.

[55] L. Jingyuan, C. Zi, H. Xiaohang, and T. Zhaoping, "Mass treatment of filariasis using DEC-medicated salt," Journal of Tropical Medicine and Hygiene, vol. 95, no. 2, pp. 132-135, 1992.

[56] M. V. Narasimham, S. P. Sharma, R. M. Sundaram et al., "Control of bancroftian filariasis by diethylcarbamazine medicated common salt in Karaikal, Pondicherry, India," Journal of Communicable Diseases, vol. 21, no. 3, pp. 157-170, 1989.

[57] A. R. Freeman, P. J. Lammie, R. Houston et al., "A communitybased trial for the control of lymphatic filariasis and iodine deficiency using salt fortified with diethylcarbamazine and iodine," American Journal of Tropical Medicine and Hygiene, vol. 65, no. 6, pp. 865-871, 2001.

[58] D. W. Meyrowitsch, P. E. Simonsen, and S. M. Magesa, "Longterm effect of three different strategies for mass diethylcarbamazine administration in bancroftian filariasis: follow-up at 10 years after treatment," Transactions of the Royal Society of Tropical Medicine and Hygiene, vol. 98, no. 11, pp. 627-634, 2004.

[59] I. P. Sunish, R. Rajendran, T. R. Mani, A. Munirathinam, A. P. Dashb, and B. K. Tyagi, "Vector control complements mass drug administration against bancroftian filariasis in Tirukoilur, India," Bulletin of the World Health Organization, vol. 85, no. 2, pp. 138-145, 2007.

[60] I. P. Sunish, R. Rajendran, T. R. Mani et al., "Resurgence in filarial transmission after withdrawal of mass drug administration and the relationship between antigenaemia and microfilaraemia—a longitudinal study," Tropical Medicine and International Health, vol. 7, no. 1, pp. 59-69, 2002.

[61] P. E. Simonsen, D. W. Meyrowitsch, D. A. Mukoko et al., "The effect of repeated half-yearly diethylcarbamazine mass treatment on Wuchereria bancrofti infection and transmission in two East African communities with different levels of endemicity," American Journal of Tropical Medicine and Hygiene, vol. 70, no. 1, pp. 63-71, 2004.

[62] P. Esterre, C. Plichart, Y. Sechan, and N. L. Nguyen, "The impact of 34 years of massive DEC chemotherapy on Wuchereria bancrofti infection and transmission: the Maupiti cohort," Tropical Medicine and International Health, vol. 6, no. 3, pp. 190-195, 2001.

[63] E. Michael, M. N. Malecela, M. Zervos, and J. W. Kazura, "Global eradication of lymphatic filariasis: the value of chronic disease control in parasite elimination programmes," PLoS ONE, vol. 3, no. 8, Article ID e2936, 2008.

[64] E. Michael, M. N. Malecela-Lazaro, and J. W. Kazura, "Epidemiological modelling for monitoring and evaluation of lymphatic filariasis control," Advances in Parasitology, vol. 65, pp. 191-237, 2007.

[65] K. Awadzi, D. A. Boakye, G. Edwards et al., "An investigation of persistent microfilaridermias despite multiple treatments with ivermectin, in two onchocerciasis-endemic foci in Ghana," Annals of Tropical Medicine and Parasitology, vol. 98, no. 3, pp. 231-249, 2004.

[66] R. K. Prichard, "Markers for benzimidazole resistance in human parasitic nematodes?” Parasitology, vol. 134, no. 8, pp. 1087-1092, 2007.

[67] A. E. Schwab, D. A. Boakye, D. Kyelem, and R. K. Prichard, "Detection of benzimidazole resistance-associated mutations in the filarial nematode Wuchereria bancrofti and evidence for selection by albendazole and ivermectin combination treatment," American Journal of Tropical Medicine and Hygiene, vol. 73, no. 2, pp. 234-238, 2005.

[68] A. E. Schwab, T. S. Churcher, A. J. Schwab, M. G. Basáñez, and R. K. Prichard, "An analysis of the population genetics of potential multi-drug resistance in Wuchereria bancrofti due to combination chemotherapy," Parasitology, vol. 134, no. 7, pp. 1025-1040, 2007.

[69] J. Mccarthy, "Is anthelmintic resistance a threat to the program to eliminate lymphatic filariasis?" American Journal of Tropical Medicine and Hygiene, vol. 73, no. 2, pp. 232-233, 2005.

[70] A. Hoerauf, "Filariasis: new drugs and new opportunities for lymphatic filariasis and onchocerciasis," Current Opinion in Infectious Diseases, vol. 21, no. 6, pp. 673-681, 2008.

[71] A. Hoerauf, S. Mand, K. Fischer et al., "Doxycycline as a novel strategy against bancroftian filariasis - Depletion of Wolbachia endosymbionts from Wuchereria bancrofti and stop of microfilaria production," Medical Microbiology and Immunology, vol. 192, no. 4, pp. 211-216, 2003.

[72] M. J. Taylor, W. H. Makunde, H. F. McGarry, J. D. Turner, S. Mand, and A. Hoerauf, "Macrofilaricidal activity after doxycycline treatment of Wuchereria bancrofti: a doubleblind, randomised placebo-controlled trial," Lancet, vol. 365, no. 9477, pp. 2116-2121, 2005.

[73] A. Y. Debrah, S. Mand, Y. Marfo-Debrekyei et al., "Macrofilaricidal effect of 4 weeks of treatment with doxycycline on Wuchereria bancrofti," Tropical Medicine and International Health, vol. 12, no. 12, pp. 1433-1441, 2007.

[74] A. Y. Debrah, S. Mand, Y. Marfo-Debrekyei et al., "Reduction in levels of plasma vascular endothelial growth factor-A and improvement in hydrocele patients by targeting endosymbiotic Wolbachia sp. in Wuchereria bancrofti with doxycycline," 
American Journal of Tropical Medicine and Hygiene, vol. 80, no. 6, pp. 956-963, 2009.

[75] J. D. Turner, S. Mand, A. Y. Debrah et al., "A randomized, double-blind clinical trial of a 3-week course of doxycycline plus albendazole and ivermectin for the treatment of Wuchereria bancrofti infection," Clinical Infectious Diseases, vol. 42, no. 8, pp. 1081-1089, 2006.

[76] A. Y. Debrah, S. Mand, S. Specht et al., "Doxycycline reduces plasma VEGF-C/sVEGFR-3 and improves pathology in lymphatic filariasis.," PLoS Pathogens, vol. 2, no. 9, article e92, 2006.

[77] M. V. Weerasooriya, N. K. Gunawardena, M. Itoh, X. G. Qiu, and E. Kimura, "Prevalence and intensity of Wuchereria bancrofti antigenaemia in Sri Lanka by Og4C3 ELISA using filter paper-absorbed whole blood," Transactions of the Royal Society of Tropical Medicine and Hygiene, vol. 96, no. 1, pp. 4145, 2002. 


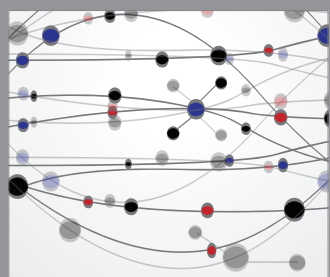

The Scientific World Journal
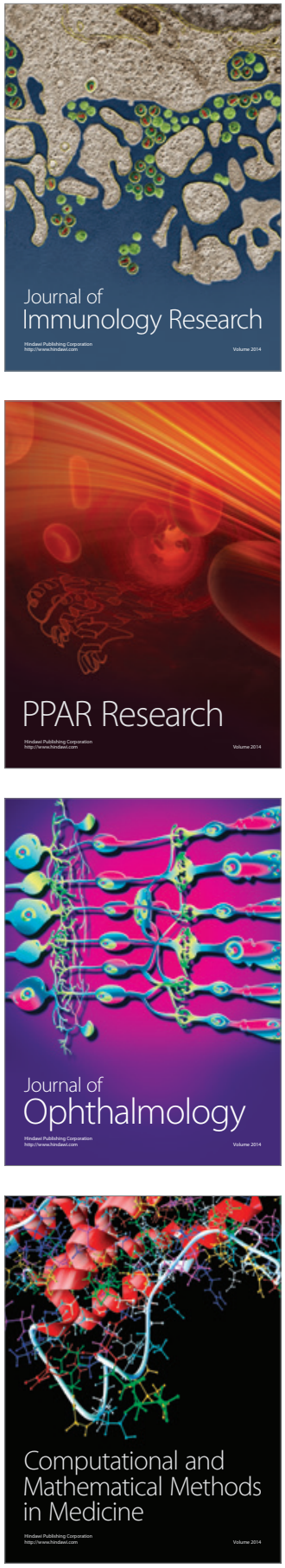

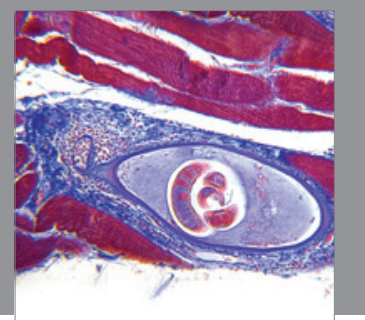

Gastroenterology

Research and Practice
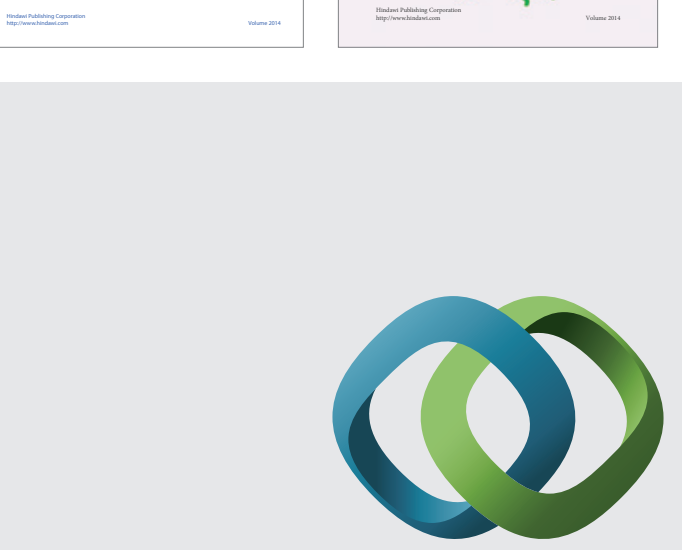

\section{Hindawi}

Submit your manuscripts at

http://www.hindawi.com
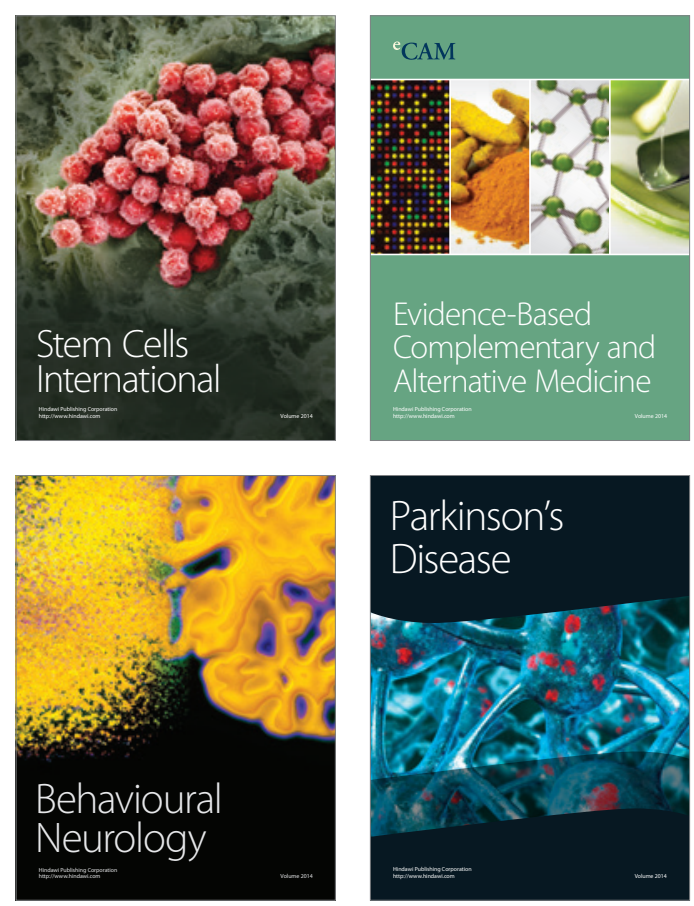

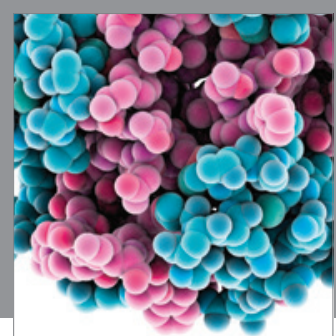

Journal of
Diabetes Research

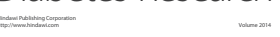

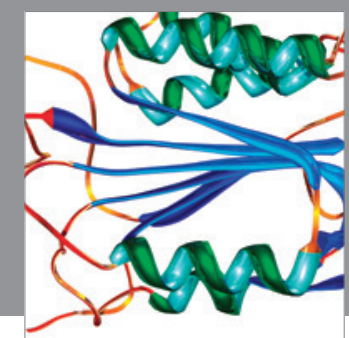

Disease Markers
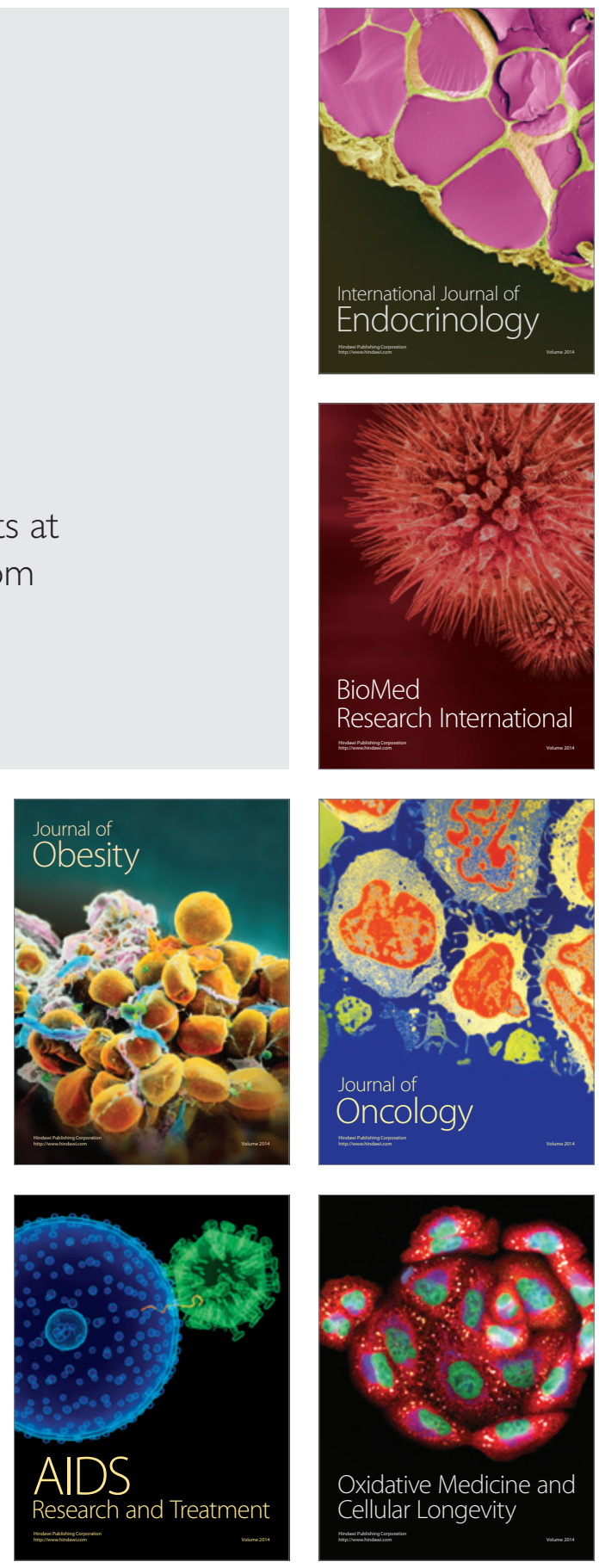